\title{
Discussing empirical research on the language and culture relationship to inform English as an additional/foreign language pedagogy and teacher education
}

\author{
Gloria Gil \\ Universidade Federal de Santa Catarina \\ glorigil@gmail.com \\ Renata Gomes Luis \\ Universidade Federal de Santa Catarina \\ renata@teachers.org
}

\begin{abstract}
In spite of the existence of a substantial body of theoretical literature that deals with the intersection of language and culture in the field of English as a foreign/additional (EA/FL) language teaching and learning, there are very few empirical studies that investigate this issue with real teachers and learners. Therefore, the objective of this paper is to review some of those empirical studies with a view to informing additional/foreign language pedagogy and teacher education. For that, the paper, first, summarizes some of the main theoretical issues by discussing the different ways in which the relationship of language and culture has been subjacent to EA/FL pedagogies. Then, the paper shows that there are three different types of language-and-culturerelated empirical studies: on coursebooks, on teacher cognition, and on classroom interaction and teacher cognition. A review of these types of studies is made by discussing their main findings. Finally, the paper brings about some implications for the field from the findings of the empirical studies and proposes some topics for further research.
\end{abstract}

Key-words: Culture and language relation. English as an additional/foreign language. Empirical studies.

\section{Resumo}

Apesar da existência de uma vasta literatura teórica que lida com a interseção entre língua e cultura na área de ensino e aprendizagem do inglês como língua 
adicional/estrangeira (LA/E), existem poucos estudos empíricos que investigam essa questão com professores e alunos reais. Portanto, o objetivo deste trabalho é revisar alguns desses estudos empíricos com o intuito de contribuir com a pedagogia e a formação de professores de inglês como LA/E. Para isso este trabalho, em primeiro lugar, resume algumas das principais questões teóricas, discutindo as diferentes maneiras em que a relação entre língua e cultura tem subjazido às pedagogias do Inglês como LA/E. Em seguida, o trabalho mostra que há três tipos de estudos empíricos que lidam com a intersecção língua-cultura: estudos sobre livros didáticos, estudos sobre crenças/concepções de professores, e estudos sobre a interação de sala de aula e as crenças/concepções dos professores. Uma revisão desses diferentes tipos de estudos empíricos é feita ao se discutir suas principais descobertas. Finalmente, o artigo traz algumas implicações para a área a partir dos resultados dos estudos empíricos e propõe alguns tópicos para futuras pesquisas.

Palavras-chave: Relação entre língua e cultura. Inglês com língua adicional/estrangeira. Estudos empíricos.

\section{Introduction}

Since the 1980's there has been a movement towards the inclusion of culture as essential component of the processes of teaching and learning of English as an additional/foreign language ${ }^{1}$. This

${ }^{1}$ Lately, some applied linguists have advocated changing the term 'foreign language' for 'additional language'. One of the reasons for this change is that the construct of 'foreign language' is deeply tainted with the myth of the native speaker supremacy and the prejudice that exists towards those who do not learn a language as a first one. In this regard, according to Saraceni (2009, p. 184), today "English should not be presented and taught as a foreign language, and hence as somebody else's language, but as an additional language to be added to one's linguistic repertoire." This idea is complemented by Judd, Tan and Walberg, for whom "teaching additional languages means teaching a second, third or further language within students' countries of origin or in countries to which they have migrated" (2001, p. 3). In Brazil, the term has been employed in the document with curriculum guidelines for the teaching of Spanish and English in the State of Rio Grande do Sul (RIO GRANDE DO SUL, 2009), for similar reasons. These guidelines suggest that, in many cases, such as immigrant families, Brazilian-sign language users and native-Brazilians, the language which is being learned is 
movement has had as main assumption the inseparability of language and culture, a close relation that has been long attested (KRAMSCH, 1998, p. 65). Nevertheless, in the field of applied linguistics, the language and culture relationship in the foreign/additional language classroom has been, and still is, a superficially understood issue. One of the reasons for this problem is that although there are many theoretical accounts regarding this issue, there is a lack of empirical studies. Thus, in order to address this problem and contribute to a needed debate in applied linguistics and, in turn, inform English as an additional language pedagogy, this paper aims at reviewing some of the few empirical studies that had been conducted. In order to do this, we will first discuss some different theoretical ways in which the relationship of language and culture has, in a veiled or unveiled way, been underlying English-as-an additional/foreign-language (EA/FL) pedagogies. After that, the highly essentialist way in which culture has usually been dealt with by EA/FL pedagogies is highlighted and the dangers underlying this essentialist view are exposed. After that, and in the light of the theorizations presented in the first sections, some findings from empirical studies which investigate the role of culture and/or the culture and language intersection in EA/FL classrooms will be presented and discussed. Finally, some pedagogical implications will be discussed and some topics for further research will be proposed.

\section{The language and culture intersection in EF/AL pedagogies across time}

Some applied linguists, such as Corbett (2003), Kramsch (1996), Lo Bianco et al. (1999), and Stern (1992) attempt at tracing the history of language and culture teaching and learning in English

added to the one(s) that the learner already has. The document also stresses that additional languages, such as English and Spanish, can be used for both intra-national and transnational communication and are essential for expression and participation in society. In this paper, although we prefer the term 'additional language' for the reasons already stated, we have decided to keep both, as most of the authors cited use the term 'foreign language'. 
language classrooms. Stern (1992, p. 206), for instance, suggests that in the history of language pedagogy, there were two main concepts of culture associated with two historical periods, before and after World War II. In the first concept, before World War II, culture teaching meant teaching the great accomplishments of the target community in arts, music, drama, and also its history, geography, and institutions. However, after World War II, the growth of social sciences led to an emphasis on a more anthropological understanding of culture as the 'way of life' of a community, namely, its typical behavior in daily situations. This new emphasis resulted from "the application to modern western societies of a concept of culture which derived from anthropological studies of tribal societies in the inter-war years" (STERN, 1992, p. 207).

Erickson (1997, p. 38) makes a similar distinction between visible and invisible aspects of culture that has been used to understand what role culture plays in classroom interaction. For Erickson (1997), the visible aspects of culture are easy to be identified as they are explicit, such as ways of dressing, types of food, housing and geographic factors. On the other hand, the invisible aspects refer to aspects that are more difficult to recognize, as they are many times imperceptible to natives of the culture, such as beliefs, values and perspectives on time, for example, what constitutes being late, and what topics are to be avoided in initial conversation with people we do not know. The next subsections aim at discussing more deeply the main approaches to language and culture developed in language pedagogy: traditional approaches, the communicative approach and the intercultural approach.

\subsection{Traditional approaches: using language as the conduit of culture}

Traditional models for culture teaching within language education have tended to approach culture as a somewhat fixed and static entity made up of things, products and facts that could be taught and learned. In these models, culture is separated from language, and language is the medium through which culture can be accessed, i.e., language is the conduit of culture. According to Lo Bianco et al (1999, p. 18), one of these models for culture teaching is related to the 
traditional teaching of literature as a high culture that is mediated through written language. Culture learning in this view means "knowing a valued text, rather than viewing the text as a window onto broader aspects of culture" (LO BIANCO et al, 1999, p. 18). Another traditional approach discussed by Lo Bianco et al $(1999$, p. 18) is, what they call the 'Culture Studies' approach'. Starting in the 70s, this paradigm viewed culture as area studies, as learning about the geography, history and institutions of the target language country in "a tourist-like way, in which the learner knows about the country, but remains external to it" (LO BIANCO et al, 1999, p. 18). According to Kramsch (1996), in this second approach, there is a separation between language and culture, given that language is the mere conduit for the transmission of a cultural knowledge that exists out there independent from language. Therefore, both the traditional Literature and the 'Culture Studies' approaches, in their own ways, emphasize culture learning as learning about the target community as a fixed and static entity and consider language as the medium to transmit information about culture.

\subsection{The communicative approach: using the native speaker's language to function in any 'culture'}

Another approach to teaching language and culture, called by Lo Bianco et al (1999) the Social Practices Approach, became famous in the 1980s. The central aim of this approach is to learn the practices that characterize a certain society, namely, what people from this society are more likely to do and how they value these actions. Gimenez (2002) contends that the 'cultural as social practice's approach comprises what became known, in the 70's and 80's, as the communicative approach, mainly based on the teaching/learning of notions and functions (p. 3). From the perspective of the functionalnotional communicative approach, culture learning seemed to be mainly related to learning how to perform pragmatic functions of

2 The definition used by Lo Bianco et al (1999) regarding the 'Culture Studies' approach in language education has no relation whatsoever with the field of cultural analysis developed by British academics in the 50s, 60s and 70 s, also called Cultural Studies. 
language in order to fulfill universal human needs. In this respect, Kramsch (1996) argues that although the communicative approach was developed to meet the needs of local speakers and hearers and, thus, to serve more democratic social goals, the reliance on universal speech functions to meet those needs is problematic in that it associates universal human needs to universal ways of thinking and talking about those needs (p. 5). She also considers that approach problematic as it neglects seeing culture as "difference, variability, and always a potential source of conflict when one culture enters into contact with another" (KRAMSCH, 1993, p. 1).

In a similar vein, Corbett (2003) argues that culture was downplayed by the communicative approach, especially because there was an emphasis on the transactional (or pragmatic) orientation of the communicative language teaching, and he suggests that "its focus on knowledge of how to do things with language - had overshadowed its cultural aspects" (p. 21). Corbett (2003) sustains that sociolinguistics promised to contribute with a cultural perspective to communicative language teaching, but he contends that these promises were fulfilled only up to some extent, for example, in the study, description and teaching of politeness formulae, while some other aspects, such as "the social construction of self and others, have been comparatively neglected" (p. 10). Lo Bianco et al (1999) also criticize the communicative approach as it leaves the learner "primarily within his/her own cultural background, observing and interpreting the words and actions of an interlocutor from another cultural background" (p. 9).

\subsection{The intercultural approach: the need to establish a third space for language and culture}

The intercultural approach was developed to overcome some of the main drawbacks of communicative language teaching, such as its exclusive concern with skills and functions for language use. This approach tries to restore the importance of content and context and proposes a way of teaching/learning language and culture "in terms of the establishment of a sphere of interculturality" (KRAMSCH, 1993, p. 205). In other words, F/A language learning can take place in a 'third space', which is considered a hybrid one that combines the culture(s) of the language being taught and the social characteristics of 
the learner's environment (KRAMSCH, 1993, p. 205). This idea is based on the premise that language and culture are inseparable and that, as learners acquire a new language they will also be acquiring a new culture. However, this culture is not expected to be the same of the learners' native culture or the culture of the language they are studying.

For Kramsch (1993), learners should locate themselves in a site which "grows in the interstices between the cultures the learner grew up with and new cultures he or she is being introduced to" (p. 236). This metaphor highlights two interrelated aspects of the intercultural approach: the learners' newly achieved distance from both the home and target cultures, and the multiplicity of cultural identities that belong to all of us, thereby rejecting the fallacy of "one nation = one culture". Therefore, the approach gives as much prominence to the learners' home culture as to the target language's culture(s) and the language classroom becomes a third place for comparison and discussion of cultures.

Several authors, such as Byram et al. (2002), Corbett (2003), Crozet and Liddicoat (1999; 2005), and Kramsch (1993), have emphasized, in different ways, that an intercultural approach to teaching/learning should not aim at developing learners' native-like communicative competence but intercultural competence. This competence would entail understanding the language and behavior of the target community and explaining it to the 'home' community and vice versa. Corbett (2003) suggests that an intercultural approach to language teaching and learning is an attempt to value and bring to the fore students' home culture, helping them acquire strategies for the systematic observation of behavioral patterns in their own and the target language, that is, training them to be ethnographers (p. 34). Furthermore, for Byram et al. (2002), the intercultural dimension in language teaching should make students act as mediators in the intercultural process where stereotypes should be avoided. They acknowledge that this dimension does not devalue linguistic competence but it is complementary to it and by developing knowledge, skills, attitudes and values, called 'savoirs', students become intercultural speakers and mediators (BYRAM et al, 2002, p. $11)$. 
Therefore, it is possible to state that central to an intercultural approach is the fact that the perception of our own culture and the culture of the other(s) is never direct but always tainted by the lenses of our own culture and that is why we usually have a somehow stereotyped view of both. It is also necessary to point out that Kramsch (1993) suggests that it is fundamental for learners to be able to create a third place, i.e., a place of mediation between their own culture and the culture of the other (p. 234). One of Byram et al's (2002) savoirs, intercultural attitudes (savoir être) closely matches Kramsch's ideas. This savoir means being able to reflect upon ones' own values and beliefs, to understand that they are not the only correct ones, and to see how these values and beliefs might look from an outsider's point of view, from someone who has different values, beliefs and behaviours. In order to have this savoir, it is necessary to have attitudes of openness and curiosity and by opening up, the learner within the third place can start a movement of decentering.

\section{The problem of the essentialist view of language and culture as 'national'}

The standard concept of culture in foreign language teaching has traditionally linked language to a national territory (RISAGER, 2007, p. 1) and its most dominant view of culture has defined it as geographically and nationally distinct entities providing rules and norms that determined personal behavior (ATKINSON, 1999, p. 626). This essentialist view of culture as 'national culture', which underlies most EF/AL pedagogies (even some intercultural oriented authors sometimes still conceptualize culture as being national), has been seriously put at stake by Holliday (1999) who suggests that this has been the default way to see cultures and alerts us to the dangers it may cause (p. 1).

Likewise, Kumaravadivelu (2008) criticizes the view of culture that, for a long time, has informed foreign language education. In this view, there is a $\mathrm{C} 1$ (native culture) associated to a $\mathrm{L} 1$ (native language) and a C2 (target culture) associated to a L2 (target language). Furthermore, Kumaravadivelu (2008) makes a strong case for emphasizing how pedagogical approaches to foreign/additional 
language teaching and learning have failed to acknowledge how language, culture, and their relationship have been and are being affected by the processes of globalization. Thus, as he sees the learning of a new language as a process of reconstruction of (cultural) identities, Kumaravadivelu (2008) strongly supports the construction of students' identities on a strong foundation of global cultural consciousness. For him, for that to happen, language teachers should not confine the teaching of culture to the culture of the target language community (national culture) or the comparison of his own with the other culture alone but rather when they should give students the opportunity to discuss the multiplicity of realities and cultures that are out there in the world.

Reflecting on the language classroom, Risager (2007) also argues that much present-day foreign language teaching still has a bilateral scheme - between students' national culture and the national culture of the target language countries. She criticizes the underlying assumption that in order to learn a language students should also learn "about cultural phenomena in the countries where the target language is spoken" (RISAGER, 2007, p. 9). Similarly to Kumavaradivelu, she contends that language teaching is a sociocultural and institutional activity inserted in the contemporary global flow of meaning and emphasizes how languages spread across cultures and cultures spread across languages.

For both Kumaravadivelu and Risager, cultural globalization and transnational processes positively influence language students in language classrooms as they place the focus on the many cultural groups individuals belong to, such as an extended family or a professional organization, and the many identity possibilities they have available in the globalized world. In this sense, the language classroom is much more than a third place between the national culture of learners and the national culture of the native speakers: it is a mixture of national, regional, group, and professional cultures. 


\section{Three types of empirical studies on language and culture and interculturality in EA/FL}

The previous sections have aimed at summarizing the main theoretical aspects of the intersection of language and culture in the teaching and learning of English as A/F language. As already suggested in the introduction, even though there is a great number of theoretical studies on the language and culture relationship in EA/FL pedagogy and interculturality, there are few empirical studies investigating these issues with real people and in real classrooms. Therefore, unfortunately, most of this debate remains mainly at a theoretical level without relating it to what actually happens in classrooms with real teachers and learners.

To contribute to the debate, this section, thus, aims at reviewing some of the few studies that empirically investigate language and culture and/or interculturality issues in EF/AL, to show the types of studies that can be distinguished and to discuss their findings. A corpus of 37 studies was built up and the studies were sorted out into three main types. One type relates to the studies of the cultural aspects of coursebooks (for example, MATSUDA, 2002; CAUKILL, 2011; FERREIRA et al, 2014). A second type includes those studies that investigate teacher cognition by means of questionnaires and/or interviews to find out their conceptions and or/beliefs on language and/or culture and their relationship (for example, RYAN, 1994; STAPLETON, 2000; FORLIN, 2009; GEBIEN, 2013). A third type of study relates to those that mainly focus on teachers' cognition together with teachers' and learners' interaction in real classrooms to understand the role that language and culture and interculturality play in them (for example, SARMENTO 2004; MENARD-WARWICK, 2009; OLIVEIRA, 2009; VOLPATO, 2014).

\subsection{Studies on the cultural aspects of textbooks}

Studies about the cultural aspects of textbooks have been the ones more extensively carried out. These studies are mainly critical because as their contents are ideologically loaded, the analysis aims at understanding their hidden ideological representations. In the 19 
reviewed studies, some of the main aspects investigated are: the cultures being privileged and how they are portrayed (e.g., CAUKILL, 2008) critical issues such as gender and race (e. g., FERREIRA et al, 2014), and the myth of the native speaker (MATSUDA, 2002). Other studies do not have a specific focus and investigate coursebooks in a more holistic way. One example of that is Risager (1991), who analyses a corpus of coursebooks of English language teaching (ELT) from the 60's, 70's and 80's, and comes to the conclusion that although along those years there were certain changes in the treatment of some cultural issues such as a more egalitarian representation of men and women and the inclusion of some examples of World Englishes' varieties, some characteristics remained the same regardless the time of production. One of these characteristics is that books have in common a definite sociocultural focus: people from the middle class, or from a socially indefinable class, living in an urban environment, who have as main role to be 'consumers' and carry out rather trivial linguistic interaction in situations of spare time and consumption. Another characteristic is that the characters in the books have no subjectivity and feelings and there is a clear orientation to including touristic or services contexts. Also, there is a strong tendency of using a neutral style to avoid any topics that can bring about conflicts (taboos, sex, religion, etc.).

According to Caukill, (2011), more recent critical studies on coursebooks reflect two orientations (p. 60). One is that coursebooks still have a strong focus on western culture and ideology, mainly inner circle countries such as England, the USA and Australia, with little or no inclusion of the other cultures, thus offering learners little space for developing intercultural learning. One example is Basabe (2004) who, after analyzing four series of textbooks used in Argentina, found out that representations of the Anglo-American culture are still quantitatively and qualitatively favored in ELT textbooks.

The other orientation is reflected in books which focus on only the local culture or no culture at all, rejecting all forms of hegemonic notions altogether. For example, Shardakova and Pavlenko (2004), who have studied the representations of cultural identities in two Russian language textbooks, conclude that neither of the analyzed books fully reflects the diversity of contemporary Russian society and that the biased stereotypical representations identified in the texts may 
deprive the students of important means of self-representation and at times even self-defense (p. 25). Furthermore, in the two orientations, cultural presentation still remains at the traditional knowledge-oriented level and does not promote deep levels of reflection.

Another problem, specifically derived from the analysis of business English coursebooks has revealed that in most cases the interactions featured do not seem to derive from real-life. Thus, the material does not seem to capture the dynamic nature of actual workplace interactions (ANGOURI, 2010). Therefore, typical ESP textbook material often depicts workplace interactions, and therefore the workplace in general, as being homogenous while findings of research on workplace talk pinpoint that there is a "variation on discourse norms and practices (according to factors such as the topic, setting, relationship of interactants to name but few)" (ANGOURI, 2010, p. 211).

Furthermore, according to Gray (2010) "the representations of the world of work in textbooks from the late 1970s until the present" have demonstrated how these coursebooks have been fueled "on evolving discourses of the new capitalism" (p. 210). He stresses that by these representations the "students are repeatedly interpellated in these materials to the subject position of white-collar individualism in which the world of work is overwhelmingly seen as a privileged means for the full and intense realization of the self along lines determined largely by personal choice" (GRAY, 2010, p. 210)

Paradoxically, while the analysis of coursebooks as cultural resources and cultural artefacts has been extensively carried out, they have seldom been linked with or included in classroom-based studies that investigate how culture is constructed and dealt with in the classrooms.

Moreover, Cortazzi and Jin (1999) investigate different EF/AL teaching materials and show that coursebooks are important artifacts that can reflect culture in three manners: as cultural mirrors of the source culture, of the target culture, or of an international target culture in which English is not spoken as a first language. Nevertheless, they suggest that these mirrors are not enough to develop learners' intercultural competence. In other words, they contend that although books might be interesting as they mirror a range of social groups and 
can "offer cultural mirrors", intercultural learning will depend mainly on the interaction among students, teachers and texts (p. 210).

Therefore, and based on Cortazzi and Jin's insights, we can suggest that the research on cultural and intercultural aspects of coursebooks is incomplete without an investigation about what happens with real teachers and learners in real interactions. At the same time, as some authors have shown, as teachers and learners' actual practices are strongly shaped by people's perceptions or beliefs, these also deserve to be investigated. Below, we will review some studies that have dealt with that issue.

\subsection{Studies on teachers' cognitions and culture}

Within the field of teacher education, understanding teacher beliefs/conceptions is important for two main reasons. One of them is that teachers' actions are guided/influenced by their beliefs. Another reason is that teachers' beliefs may have impact on students' beliefs (WOODS, 1996). Therefore, some studies carried out in this area can throw some light on how teachers conceptualize culture and how they see language and culture in pedagogical terms. Thus, the second type of study reviewed here refers to research that can be situated within the area of teacher cognition. The ten studies reviewed were carried out in different countries, such as Mexico (RYAN, 1994, 1998), China (LESSARD-CLOUSTON, 1996), Japan (STAPLETON, 2000), and Brazil (GEBIEN, 2013). These studies raise questions and discussions about the role of teachers and their perceptions about the interface of language and culture.

Many of the studies revealed that even though most teachers think that dealing with culture in the additional/foreign classroom is very important, they feel insecure when dealing with culture and the language and culture relationship (for example, LESSARDCLOUSTON, 1996; GEBIEN, 2013). These studies have been usually carried out by means of questionnaires and/or interviews, and their findings have shown that it is very difficult for teachers to reflect about their pedagogic approaches to culture in the EA/FL classroom (for example, GEBIEN, 2013). The studies of Gebien (2013, p. 100) and Stapleton $(2000$, p. 296) have shown that many teachers conceptualize language and culture as social practice, are aware of their relationship 
and realize the importance of dealing with language and culture together. In addition, Forlin (2009) and Gebien (2013) suggest that the investigated teachers in their studies do acknowledge that language and culture are two sides of the same coin and cannot be separated. Nevertheless, Forlin's (2009) shows that the participants of her study, in-service teachers and teachers' educators, report to be usually teaching EFL in a traditional way, emphasizing structural elements of the language and teaching isolated cultural aspects (p. 69).

In addition, in most of the studies reviewed, the definitions of culture provided by teachers appear to be lacking in depth and complexity for language teaching (BYRAM; RISAGER, 1999) and sometimes teachers make use of metaphorical language to bring about definitions of culture (RYAN, 1996, p. 576). Thus, the studies stress the highly personal nature of the concept of culture (RYAN, 1996, p. 8). Furthermore, Gebien (2013) investigates teachers' perceptions and/or beliefs on culture as a preliminary to exploring interculturality in classroom contexts. In other words, the study attempts to see up to what an extent the teachers investigated had an intercultural orientation. The findings suggest that most of the teachers still see the teaching and learning of culture and intercultural competence in terms of the transmission of knowledge, rather than in terms of helping learners to become intercultural communicators, that is, in terms of having a new, more open attitude towards others and their own cultures or being able to decenter. In addition, the teachers in Gebien (2013) define interculturality as comparisons between native culture and target culture, and, in those comparisons, the native and the target cultures are understood as national cultures (GEBIEN, 2013, p. 100-101). Thus, the investigated teachers seem to fail to see the transnational nature of the language and culture relationship (RISAGER, 2007, p. 16-17).

Finally, the studies reviewed here have shown the idiosyncratic, traditional and even essentialist ways in which teachers view culture. Nevertheless, the picture is still incomplete, so in the next section, we will review some studies that deal with both teachers' beliefs and the actual interactions among teachers and students in classrooms. 


\subsection{Studies on teachers' cognition, classroom interaction and interculturality}

More holistic empirical studies that deal with culture teaching and learning and interculturality in classroom interaction together with teachers' beliefs/ perceptions on cultural aspects are still fewer (eight studies were found and reviewed) than those which investigated culture related coursebooks representations and teachers' cognition. Some examples are Menard-Warwick (2009), Sarmento (2004), Volpato (2014), and França (2007). The first study investigated teachers and learners from Chile and USA, and the other three were carried out in Brazil.

The first study to be reviewed here is Sarmento (2004) which investigates both the beliefs on culture teaching of seven teachers and their classroom interaction with students from an English school. Based on the teachers' beliefs from interviews, she concludes that the teachers conceptualize culture in four different ways (p. 242). One way sees 'Culture as information about something,' where culture is considered a synonym of intellectuality. Another way sees 'Culture as behaviour', that is, as habits, customs and general aspects of daily life. A third way conceptualizes 'Culture as language', that is, moments when teachers deal with culturally driven aspects of language, such as the use of idioms or pragmatic rules. Finally, the fourth category inferred from the teachers' beliefs was 'Culture as history', that is, a repository of values, beliefs and material things from older times. After analyzing several moments of teacher and learners' interactions on culture, Sarmento (2004) concluded that mainly visible and isolated cultural aspects are being taught in the language classroom encouraging, many times, the creation of stereotypes, precluding the possibility of the establishment of a third place (KRAMSCH, 1993, p. 232-259), and not allowing the possibility of intercultural development (SARMENTO, 2004, p. 262). Sarmento (2004) concludes that:

The classroom practice does not offer enough opportunity for students to develop their intercultural communicative competence, since it is focused on transmitting cultural information, many times out of context or without 
Discussing empirical research on the language and culture relationship...

considering language use in social interaction. (p. 241) [our translation]

In another study, Volpato (2014) investigated the beliefs of two teachers of English from a language school regarding interculturality and the interaction of these teachers with their students. The study shows, at the same time, similar and different results from the analysis of classroom interaction in Sarmento's study. In a similar fashion, Volpato's study shows that in many moments the teachers transmit cultural aspects (culture as information, as habits and as language). Volpato (2014) also provides examples where teachers and students stereotype people, reducing complex human beings to mere representatives of a country or community. Thus, the findings from research on classroom interaction by Sarmento (2004) and partly by Volpato (2014) also show that cultural stereotypes that appear either from the book contents or as comments in the interaction were not usually problematized by the participants (p. 68).

On the other hand, the study by Volpato (2014) also presents some interactive moments which are different from Sarmento's study, when the teachers investigated did not limit themselves to transmitting cultural aspects and making stereotypical comments but were able to encourage the students to reflect upon their own essentialist comments on language and culture (p. 53). Thus, the teachers sometimes can become mediators that help students become critically aware of linguistic and cultural prejudices and stereotypes and problematize cultural aspects brought about by the coursebooks or spontaneously raised by the teachers or the students. In other words, the teachers seemed in certain moments to be aiming at developing critical intercultural attitudes. Similarly, Menard-Warwick's (2009, p. 36-37) and França's (2007, p. 90-91) studies also provide some examples of interactive situations where the teachers provide space for students to problematize cultural issues and an arena for negotiating different 'conflicting' viewpoints. Therefore, those three studies evidence the possibility for teachers to provide 'third spaces' for their students to become aware of cultural stereotypes, discuss diverse cultural issues and develop critical intercultural awareness.

Those interactive moments provided by Volpato, MenardWarwick and França, thus, can be said to have a clear intercultural 
orientation as there is an engagement in the act of meaning-making which may bring about a transformation of the learners in the act of learning. In those interactions, thus, the students engage in a practice of confronting multiple possible interpretations, which may help them to decenter. In other words, by developing a response to meaning as the result of engagement with another culture(s), the borders between self and other can be "explored, problematized and redrawn" (LIDDICOAT; SCARINO, 2013, p. 49).

Therefore, teachers who follow an intercultural orientation can be said to generally provide space for students to problematize cultural issues and foster students' reflection on cultural aspects. On the other hand, the moments depicted by Sarmento (2004), and some moments from Volpato (2014) mentioned at the beginning of this section, can be said to have a cultural orientation, where, differently from intercultural ones, the participants construct homogeneous cultural representations of groups and tend to represent and stereotype national groups only. In these kinds of interactions, which still are the most frequent, teachers are not cultural mediators but cultural knowledge transmitters. According to Liddicoat and Scarino,

a cultural orientation implies the development of knowledge about a culture [our emphasis], which remains external to the learner and is not intended to confront or transform the learner's existing identity, practices, values, attitudes, beliefs, and worldview. (2013, p. 29)

Moreover, regarding beliefs, the studies under review revealed that the teachers conceived culture as a socially constructed concept and were able to conceptualize culture as social practice, even though some of the interviewed teachers did not seem to have been in contact with intercultural teaching theories. Nevertheless, the studies of França and Volpato showed that the teachers who seemingly had less theoretical knowledge about interculturality were the ones that were able to co-construct more intercultural oriented interactions with the students. These puzzling findings may indicate that sometimes teachers may intuitively act on intercultural orientations, and that explicit knowledge about intercultural teaching does not always guarantee intercultural oriented practices. 
Interestingly, the studies that investigate both teachers' perceptions and the interactions they construct with students only incidentally mention the types of texts being used and no study includes a critical analysis of the coursebooks or other materials. This absence may indicate that even though the cultural contents of books bring about ideologically loaded representations of reality, in the long run, the dialogue between teachers and learners will construct cultural representations which are accepted and/or resisted by the participants (MENARD-WARWICK, 2009, p. 32).

\section{Final remarks: implications for EA/FL pedagogy and teacher education}

This paper is based on the assumption that in order to understand the roles of language and culture in the foreign/additional language classroom it is necessary to both theorize on the issue and investigate what happens in real classrooms and in real teachers' and learners' interaction. In this vein, therefore, we have reviewed some of the few empirical studies that investigate the language and culture intersection in EA/FL. It seems to be relevant at this point, then, to bring about and discuss the main implications from the reviewed studies that can inform EA/F language pedagogy and teacher education.

To begin with, perhaps the most important (not surprising) implication is that dealing with culture and language and propitiating interculturality still seems to be a very difficult task for most teachers. In this regard, the studies of teachers' beliefs point to the fact that teachers seem to be able to intellectually grasp certain theoretical concepts such as language and culture as social practice or interculturality, but it is very difficult for them to make the pedagogic transposition from theory into practice. Furthermore, having some theoretical knowledge does not seem to be a sufficient condition for teachers to actually perform in the classroom so as to construct intercultural moments with the students. There is here an important implication for teacher education, as this shows that only theoretical knowledge is not a sufficient condition for practice. Furthermore, the teachers' lack of knowledge about culture(s) and/or insecurity to deal 
with cultural aspects (BYRAM; RISAGER, 1999; VOLPATO, 2014; SCHULZ, 2007) can be related to the fact that language-and-culture related aspects are not usually incorporated either theoretically or practically in the EF/AL education curriculum, i.e., they may not be topics/disciplines that compose it. This means that there is a very clear gap in teacher education regarding language and culture intersection issues, a topic which should be investigated.

In that regard, the findings from classroom interaction analysis have shown the importance of teacher and learner dialogue, and the teachers' roles as mediators for the construction of intercultural understandings and the avoidance of essentializing and stereotyping cultural aspects. Therefore student-teachers' observation and analysis of real classroom interaction could be ways of bridging theoretical and practical knowledge for dealing with interculturality in the classrooms. Also, student-teachers in their own English language classrooms should be encouraged to co-construct with the teachers' cultural representations and not be mere passive consumers of cultural knowledge.

The findings from the analysis of coursebooks show that textbooks in general seem to continue bringing partial and essentializing linguistic and cultural representations, which can be very dangerous ways of alienating if used in an uninformed way. Yet, if teachers instead of teaching by the book, had a more critical stance, they could help learners deconstruct coursebook explicit and hidden ideological representations. As Cortazzi and Jin (1999) have proposed, the teachers and learners in classroom interaction can be considered 'major cultural resources' and identity negotiation as the full realization of the cultural content of textbooks ultimately depends on them (p. 210). For them, culture learning through textbooks might also be seen as a process of dialogue in which students negotiate meaning and identity vicariously with the author of the textbook and its cultural content. However, this is mediated in the classroom with a teacher who manages the way in which the students see the culture mirrored in the textbook. Teachers may not only mediate textbook content for students, but also the ways in which students see themselves (p. 210).

Another important indirect pedagogical implication from the studies, which was not mentioned before but we consider worth mentioning here, is that some teaching conditions can be a serious 
obstacle for teachers to be able to implement a more intercultural approach in their classes. Among the negative aspects of the teaching conditions mentioned by teachers (VOLPATO, 2014; SCHULZ, 2007) are limited material resources such as internet access, lack of slide projectors, textbooks without cultural-oriented activities and strict language curriculum to follow that leaves no time for intercultural activities. These are perhaps the most difficult problems to solve, as they depend on political will and educational policies.

Based on those caveats, we propose the following topics for further research:

- What types of language and culture issues are included in the curriculum of teacher education programs in Brazil?

- How are the cultural identities of teachers, student teachers and learners constructed in these programs?

- How does technology and the internet impact on the construction of interculturality in the A/F language classroom?

Finally, regarding the empirical studies, our review has shown that most of them concentrate on only one of the language and culture intersections, such as the analysis of books or teachers' beliefs and only few studies, such as Sarmento (2004) and Volpato (2014) relate them to real classroom interaction. Thus, we suggest the development of more holistic studies, ethnography-oriented that aim at capturing the complexity of the situations and include the three aspects: coursebooks (and/or other materials), teacher cognition and teacher and learners' construction of classroom interaction.

\section{References}

ANGOURI, Jo. 'If we know about culture it will be easier to work with one another': developing skills for handling corporate meetings with multinational participation. Language and Intercultural Communication, v. 10, n. 3, p. 206-224, 2010.

ATKINSON, Dwight. TESOL and culture. TESOL Quarterly, v. 3, n. 4, p. 625-654, 1999. 
BASABE, Enrique Alejandro. A critical comparative analysis of the representations of the source culture, the local culture and the international culture in global, adapted and local materials. 2004. 191p. Thesis (MA in British Cultural Studies \& English Language Teaching) - Centre for English Language Teacher Education, The University of Warwick, Warwick, 2004.

BYRAM, Michael. Teaching and assessing intercultural communicative competence. Clevedon: Multilíngual Matters, 1997.

BYRAM, Michael; RISAGER, Karen. Language teachers, politics and cultures. Clevedon: Multilingual Matters, 1999.

BYRAM, Michael, GRIBKOVA, Bella; STARKEY, Hugh. Developing the intercultural dimension in language teaching: a practical introduction for teachers. The Council of Europe, 2002.

CAUKILL, Emma. Learning English in an English-speaking world: examining opportunities for intercultural understanding and connectedness through representations of identities in English language textbooks. In: DASHWOOD, Ann; SON, Jeong-Bae (Eds.). Language, culture and social connectedness. Newcastle upon Tyne: Cambridge Scholars Publishing, 2011. p. 57-73.

CORBETT, John. An intercultural approach to second language education. London: Multilíngual Matters, 2003.

CORTAZZI, Martin; JIN, Lixian. Cultural mirrors: materials and methods in the EFL classroom. In: HINKEL, Eli (Ed.). Culture in second language teaching and learning. Cambridge: Cambridge University Press, 1999. p. 196-219.

ERIKSON, Frederick. Culture in society and in educational practice. In: BANKS, James; BANKS, Cherry (Eds.). Multicultural education: issues and perspectives. Boston: Allyn and Bacon, 1997. p. 30-60.

FRANÇA, Oldine. O discurso e a prática do professor frente ao ensino de cultura em Língua Estrangeira (inglês) e os Parâmetros 
Discussing empirical research on the language and culture relationship...

Curriculares Nacionais. 2007. 159p. Thesis (MA Applied Linguistics)

- Instituto de Letras, Universidade de Brasília, Brasília, 2007.

FERREIRA, Aparecida de Jesus; CAMARGO, Mábia. Racismo cordial no livro de Língua Inglesa aprovado pelo PNLD. Revista da Associação Brasileira de Pesquisadores(as) Negros(as) - ABPN, v. 6, p. 177, 2014.

FORLIN, Carla Maria. Concepções sobre língua e cultura na formação continuada de professores de língua inglesa: uma leitura do Núcleo de assessoria pedagógica da UFPR. 2009. 91p. Master's Thesis (MA in Letras) - Instituto de Letras, Universidade Federal de Paraná, Curitiba, 2009.

GEBIEN, Karina. A study of teachers' perceptions on cultural and intercultural aspects in public schools in Blumenau. 2013. 110p. Master's Thesis (MA in English: Language and Literature Studies) Centro de Comunicação e Expressão: Universidade Federal de Santa Catarina, Florianópolis, 2013.

GIMENEZ, Telma. Eles comem cornflakes, nós comemos pão com manteiga: espaços para a reflexão sobre cultura na sala de aula de língua estrangeira. IN: IX Encontro de Professores de Línguas Estrangeiras (EPLE), 2002. Londrina. Anais...Londrina, APLIEPAR, 2002. p. 107-114.

GRAY, John. The ELT coursebook as cultural artefact: how teachers censor and adapt. ELT Journal, v. 54, n. 3, p. 274-283, 2000.

HOLLIDAY, Adrian. Small cultures. Applied Linguistics, v. 20, p. 237-264, 1999.

JUDD, Elliot, TAN, Lin; WALBERG, Herbert. Teaching additional languages: educational practices. Series 6. Belgium: Languages and Linguistics Clearinghouse, 2001.

KILICKAYA, Ferit. Guidelines to evaluate cultural content in textbooks. The Internet TESL Journal, v. 12. 2004. Available at: 
<http://iteslj.org/Techniques/Kilickaya-CulturalContent>. Accessed on 10 May 2012.

KRAMSCH, Claire. Context and culture in language teaching. Oxford: Oxford University Press, 1993.

KRAMSCH, Claire. The cultural component of language teaching. Zeitschrift für Interkulturellen Fremdsprachenunterricht, 1996. Available at: <http://www.spz.tudarmstadt.de/projekt_ejournal/jg_01_2/beitrag/kramsch2.htm>. Accessed on 21 March 2010.

KRAMSCH, Claire. Language and culture. Oxford: Oxford University Press, 1998.

KUMARAVADIVELU, B. Cultural globalization and language education. New Haven: Yale University, 2008.

LESSARD-CLOUSTON, Michael. Chinese teachers' view of culture in their EFL learning and teaching: a case study. Language, Culture and Curriculum, v.9, n.3, p. 220-225, 1996.

LIDDICOAT, Anthony; SCARINO, Angela. Intercultural language teaching and learning. New York: Wiley and Sons, 2013.

LO BIANCO, Joseph; LIDDICOAT, Anthony; CROZET, Chantal. Intercultural competence: from language policy to language education. In: LO BIANCO, Joseph; LIDDICOAT, Anthony; CROZET, Chantal. (Eds.) Striving for the third place: intercultural competence through language education (p. 1-22). Melbourne: Language Australia, 1999.

MATSUDA, Aya. Representations of users and uses of English in beginning Japanese EFL textbooks. JALT Journal, v. 24, n.2, p. 183200, 2002.

MENARD-WARWICK, Julia. Co-constructing representations of culture in ESL and EFL classrooms: discursive faultlines in Chile and Colombia. The Modern Language Journal, v. 9, n. 1, p. 30-45, 2009. 
Discussing empirical research on the language and culture relationship...

OLIVEIRA, Adelaide. O ensino de L2 e cultura para o desenvolvimento da competência comunicativa intercultural: uma proposta transdisciplinar. In: VI Congresso Internacional da ABRALIN, 2009. João Pessoa. Anais... João Pessoa, ABRALIN, 2009, p. 11-21.

RIO GRANDE DO SUL. Secretaria da Educação. Departamento Pedagógico. Referenciais curriculares do Estado do Rio Grande do Sul. Porto Alegre: Secretaria da Educação, 2009.

RISAGER, Karen. Cultural references in European textbooks: an evaluation of recent tendencies. In: BUTTJES, Dieter; BYRAM, Michael (Eds.). Mediating languages and cultures: towards an intercultural theory of English language teaching. Clevendon and Philadelphia: Multilingual Matters Ltd, 1990. p. 181-192.

RISAGER, Karen. Language and culture pedagogy: from a national to a transnational paradigm. Clevedon: Multilíngual Matters, 2007.

RYAN, Phyllis. Sociological goals for foreign language teaching and teachers' metaphorical images of culture. Foreign Language Annals, v. 29, n.4, p. 571-86, 1996.

SARACENI, Mario. Relocating English: towards a new paradigm for English in the world. Language and Intercultural Communication, v. 9, n.3, p. 175-186, 2009.

SARMENTO, Simone. Aspectos culturais presentes no ensino da língua inglesa. In: SARMENTO, Simone; MULLER, Vera (Eds.), $O$ ensino do inglês como língua estrangeira: estudos e reflexões. Porto Alegre: APIRS, 2004. p. 241-266.

SCHULZ, Renate. The challenge of assessing cultural understanding in the context of foreign language instruction. Foreign language annals, v. 40, n. 1, Education Module, p. 9-26, 2007. 
SHARDAKOVA, Marya; PAVLENKO, Aneta. Identity options in Russian textbooks. Journal of Language, Identity and Education, v. 3, n.1, p. 25-46, 2004.

STERN, Hans Heinrich. Issues and options in language teaching. Oxford: Oxford University Press, 1992. p. 205-242.

STAPLETON, Paul. Culture role in TEFL: an attitude survey in Japan. Language, Culture \& Curriculum, v. 13, n.3, p. 292-30, 2000.

VOLPATO, Mayara. Interculturality in additional language teaching, reality or just another dream? 2014. 110p. Thesis (MA in English: Language and Literature Studies) - Centro de Comunicação e Expressão: Universidade Federal de Santa Catarina, Florianópolis, 2014.

WOODS, Devon. Teacher cognition in language teaching: beliefs, decision-making and classroom practice. Cambridge: Cambridge University Press, 1996.

Recebido em: 15/02/2016 Aceito em: 107/05/2016

Título: Discutindo pesquisas empíricas sobre a relação entre língua e cultura como contribuição para a pedagogia e a formação de professores de inglês como língua adicional/estrangeira. 